\title{
Relationship between Environmental Conditions and Nosocomial Infection Rates in Intensive Care Unit
}

Esma M. ŞiMŞEK ${ }^{1}$, Semiha S. GRASSIE², Cengizhan EMRE' ${ }^{1}$ Sümeyra Ç. GEVREK ${ }^{3}$

\footnotetext{
${ }^{1}$ Anesthesiology and Reanimation Clinic, University of Yıldırım Beyazıt Yenimahalle Teaching and Research Hospital, Ankara, Turkey.

${ }^{2}$ Infectious Disease and Clinical Microbiology Clinic, University of Yıldırım Beyazıt Yenimahalle Teaching and Research Hospital, Ankara, Turkey.

${ }^{3}$ Department of Infection Control, University of Yıldırım Beyazıt Yenimahalle Teaching and Research Hospital, Ankara, Turkey.
}

\section{ABSTRACT}

Intensive care units (ICUS) are the most important departments of a hospital regarding nosocomial infections. Many risk factors contribute to the infection rates in ICUs. These risk factors can be related to the patient or environment. Environmental conditions are important in infection control. Nurse/patient ratio has been shown to be related to nosocomial infection rates. This study aimed to investigate the effects of some of these factors on nosocomial infection rates in ICUs. The effects of changes in environmental conditions, such as area around the patient bed, temperature, humidity, and nurse/ patient rates on nosocomial infection rates were examined retrospectively in the ICU from January 2012 to June 2014 in this study.

The total infection rate, ventilator associated pneumonia rate, and catheter-related urinary tract infection rate were found to be $7.67 \%, 14.53 \%$, and $5.47 \%$, respectively. Despite a statistically significant relationship between all infection rates and the size of the area around the patient bed, no relationship was detected between the nurse/patient rates and the infection rates. Between temperature and humidity, only humidity had a statistically significant relationship with catheterrelated urinary tract infection rates.

Nurse/patient ratio is important in ICUs but the other factors related to the quality of the work and infection control are also important. The size of the area around the patient bed has been shown to have an important effect on infection control. This study reported a direct relationship of the size of the area around the patient bed with the infection rates. More studies are needed to evaluate the relationship between temperature and humidity and nosocomial infection rates.

Key words: Infection control, intensive care units, risk factors

\section{INTRODUCTION}

Intensive care units (ICUs) are important departmants at the hospital for nosocomial infections. Although an ICU has 5\%$10 \%$ of the hospital beds, $25 \%-50 \%$ of the nosocomial infections originate from the ICU $(1,2)$. Both ventilator-related pneumonia (VRP) and catheter-related urinary tract infections (CRUIs) are the most common infections in the ICU (3). Many risk factors are responsible for nosocomial infection in the ICU $(1,4)$. Some of the risk factos are related to the patient, whereas the others are related to the external factors $(1,4)$. It is known that improving the risk factors decreases the infection, mortality, morbidity, and cost $(1,3)$.

The environmental conditions affect the infection rate in the ICU $(5,6)$. The patient number in the room, being in single or multiple patient room, space in the room, and design of the room are important for infecton control in the ICU $(2,5,6,7,8)$. Generally efficient airconditioning, filter, heat, and humidity systems are important for infection control at the hospital. These systems are more important than the others in some departments such as the ICU (9). 
The number of the nurses working in the ICU is also related to the infection rate $(5,7)$. A previous study found that a decrease in nurse/patient ratio, insufficient training of the nurses, and constantly changing nurses increase the infection rate $(1,5,7)$. Working with trained nurses is important for infection control (10). Nonetheless, it is hard to determine the ideal number and quality of nurses working in the ICU.

This study aimed to determine the effects of the changes in environmental conditions such as temperature, humidity, size of the area around the patient bed, and nurse/patient ratio on the infection rates in the ICU retrospectively, thereby contributing to the creation of new standards in the ICU.

\section{MATERIALS AND METHODS}

The infection rates and changes in environmental conditions in the ICU were examined retrospectively from January 2012 to June 2014 in this study. Monthly average nurse number, bed number, patient count, the size of the area $\left(\mathrm{m}^{2}\right)$ around each patient bed, and monthly mean temperature and humidity recorded in ICU rooms were determined. In the same months, the infection rates in the ICU: total infection rates, VRP rates, and CRUI rates were also recorded. The infection rates were determined using standard surveillance criteria among the infections observed after 2 days in the ICU.

The results were evaluated using SPSS 17.00 (SPSS, IL, USA), and a $P$ value $\leq 0.05$ was accepted as statistically significant. The relationships between the infection rates: total infection rates, VRP rates, and CRUI rates, and the nurse/patient ratio, size of the area around the patient bed, temperature, and humidity were investigated.

\section{RESULTS}

The relationships between the area around the patient bed, nurse/patient ratio, temperature, and humidity, and total infection rates, VRP rates, and CRUI rates are summarized in Table 1. The total infection rate, VRP rate, and catheter-related urinary tract infection rate were $7.67 \%, 14.53 \%$, and $5.47 \%$, respectively, in the ICU.
TABLE 1: Relationship of nurse number, area around each bed, temperature, and humidity with nosocomial infection rates in the ICU.

\begin{tabular}{lccc} 
& Minimum & Maximum & Mean \\
\hline Nurse/bed ratio & 1.20 & 2.40 & 1.91 \\
$\begin{array}{l}\text { Area around patient } \\
\text { bed }\left(\mathrm{m}^{2}\right)\end{array}$ & 9.40 & 16.50 & 11.07 \\
Temperature $\left({ }^{\circ} \mathrm{C}\right)$ & 21.40 & 30.25 & 23.62 \\
Humidity $(\%)$ & 29.95 & 42.11 & 36.13 \\
Total infection rate & 0 & 38.46 & 7.67 \\
$\begin{array}{l}\text { (\%) } \\
\text { VRP rate (\%) }\end{array}$ & 0 & 51.28 & 14.53 \\
CRUI rate (\%) & 0 & 20.98 & 5.47 \\
\hline
\end{tabular}

Statistical analysis revealed no statistically significant relationship between the nurse/patient ratio and the infection rates. The area around the patient bed had a statistically significant negative correlation with total infection rate $(P=0.03)$, VRP rate $(P$ $=0.03)$, and (RUI rate $(P=0.008)$. Despite no statistically significant relationship of other infections with temperature and humidity, only CRUI rate had a negative correlation with humidity ( $P=0.001$ ) (Table 2).

\section{DISCUSSION}

The number of nurses and environmental conditions affects the nosocomial infection rate in the ICU. Some authors reported that keeping not enough number of nurses increased the infection rate in the ICU $(1,10)$. Determine the ideal nurse number for preventing nosocomial infections in the ICU is difficult. The patients' clinical condition, the nurses' certification to work in the ICU, and some other factors are effective $(10,11)$. The nurses trained about the ICU procedures are in better accordance with the infection control procedures compared with others (11). A study showed that a nurse/patient ratio of more than 2.2 decreased the infection rate by $30 \%$ in the ICU (10). The present study reported no statistically significant relationship between the infection rates and the nurse/patient ratio. The regulation about the nurse number working in the ICU is connected to the classification of the ICU in Turkey. If the ICU is a third degree, meant only for patients in a serious condition, it should have one nurse for every two patients in every shift. If the ICU is a second 


\begin{tabular}{|c|c|c|c|c|}
\hline & & ICU infections & VIP & CRUI \\
\hline \multirow[t]{2}{*}{ Nurse/bed ratio } & Correlation coefficient & -0.077 & 0.152 & -0.158 \\
\hline & $P$ & 0.685 & 0.424 & 0.404 \\
\hline \multirow[t]{2}{*}{ Area around bed $\left(\mathrm{m}^{2}\right)$} & Correlation coefficient & -0.396 & -0.397 & -0.474 \\
\hline & $\mathrm{P}$ & 0.030 & 0.030 & 0.008 \\
\hline \multirow[t]{2}{*}{ Temperature } & Correlation coefficient & 0.103 & 0.044 & 0.284 \\
\hline & $P$ & 0.587 & 0.819 & 0.128 \\
\hline \multirow[t]{2}{*}{ Humidity } & Correlation coefficient & -0.217 & -0.189 & -0.584 \\
\hline & $P$ & 0.250 & 0.317 & 0.001 \\
\hline
\end{tabular}

degree, it should have one nurse for every three patients in every shift (12). The nurse/patient ratio reported in the present study was concordant with this regulation. This is the reason why no statistically significant relationship of the nurse/patient ratio with the infection rates was found in the study. Future studies should consider not only the number but also the characteristics of nurses working in the ICU and investigate the quality factors affecting the nurse/patient ratio and infection rates, thus helping to establish new standards.

The patients in the ICU are mostly in a bad clinical condition with numerous health problems and underlying diseases. Their thermoregulation system is not working well enough. The changes in the room temperature affect the body temperature directly in the ICU patients (13). Therefore, the temperature and humidity should be maintained within specified limits in the ICU (9). The CDC environmental infection control guidelines state that the temperature should be between $20^{\circ} \mathrm{C}$ and $24^{\circ} \mathrm{C}$ and the humidity should be between $30 \%$ to $60 \%$ at the hospitals (9). The present ICU regulations specify that the temperature should be kept $22^{\circ} \mathrm{C}-28^{\circ} \mathrm{C}$ and the humidity should be $30 \%-60 \%$ (12). The prevalence of some of the gram-negative bacterial infections, such as Acinetobacter spp., increases in the hot weather $(14,15)$. Gram-negative bacteria infections are the problematic infections in the ICU because of their increasing resistance to antibiotics $(3,16)$. The present study found no relationship of temperature and humidity with the infection rates. The humidity was within limits, and the temperature exceeded the limits only for a short time. No major differences in these measurements were found.
This was the reason why a relationship of temperature and humidity with the infection rates was not found. A statistically significant relationship was observed between humidity and catheter-related urinary tract infection rate in the present study. Few studies determined the relationship of increasing temperature and humidity with the nosocomial urinary tract infection caused by Pseudomonas aeruginosa. Some other studies linked urinary tract infections with high temperature and low humidity $(17,18,19)$. The relationship between humidity and urinary tract infection needs to be further investigated before reaching any definite conclusions.

The design of the ICU, having enough isolation rooms, area for each patient, and number of patients sharing the same room are related to the nosocomial infection rate $(5,6,8)$. The area around the patient bed has a number of microorganisms (19). Therefore, the design of the room and the number of patient beds and surfaces in the room are important factors for infection control (20). An ideal ICU should have at least an area of $20 \mathrm{~m}^{2}$ with a single bed (6). The regulations about ICU beds specify at least $12 \mathrm{~m}^{2}$ for each bed and at least 1.5-m distance between the two beds (12). The present study reported a negative correlation between the infection rates in the ICU and the size of the patient bed. This is thought to be an important finding. Because of an increasing demand of ICU beds, accepting more patients in ICU rooms might cause an increase in infection rates. Even if it is difficult to provide the ideal conditions, the compliance to the standards is important. At least the regulations related to the ideal conditions should not be disregarded $(6,12)$. 
Although the present study did not find any statistically significant relationship with the infection rates, it is still believed that the number and qualification of the nurses working in the ICU are important in preventing nosocomial infections. Beside the standard number, qualification standards should also be established. The distance between the patient beds is important for infecton control. Hence, designing an ICU has increasing importance. Temperature and humidity can affect the nosocomial infection rates. Further studies are needed to investigate the exact relationship of internal and external factors with nosocomial infections in the ICU.

\section{REFERENCES}

1. Barsanti MC, Woeltje KF. Infection Prevention in the Intensive Care Unit. Infect Dis Clin N Am 2009;23:703-25.

2. Harvey MA. Critical Care Unit Bedside Design and Furnishing: Impact on Nosocomial Infections. Infect Control Hosp Epid 1998;19(8):597-600.

3. Custovic A, Smajlovic J, Hadzic S,Ahmetagic S, Tihic N, Hadzagic $\mathrm{H}$. Epidemiological Surveillance of Bacterial Nosocomial Infections in th Surgical Intensive Care Unit 2014;26(1):7-11.

4. Crehuet RF, Molina CD, Irala J, Concha DM, Leal IS, Calles JM. Nosocomial infection in an intensive care unit: identification of risk factors. Infect Cont Hosp Epidem 1997;18(12):825-30.

5. Nyström B. Optimal Design/Personnel for Control of Intensive Care Unit Infection. Infection Control 1983;4(5):388-90.

6. O'Connel $\mathrm{NH}$, Humphreys $\mathrm{H}$. Intensive care unit design and environmental factors in acquisition of infection. J Hosp Infect 2000;45(4):255-62.

7. Yılmaz M. Yoğun Bakım ünitesi Persolnelinin Yapılandırılması Ve İnfeksiyon Açısından Önemi. Türk Yoğun Bakım Derneği Dergisi 2003;2(2):24-6.

8. Thompson DR, Hamilton DK, Cadenhead CD, Swoboda SM, Schwindel SM, Anderson DC, Schmitz EV. Guidelines for intensive care unit design. Crit Care Med 2012; 40(5):1586-1600.

9. HICPAC, CDC 2003 Guidelines for Environmental Infection Control in Health-Care Facilities.
10. Hugonnet S, Uçkay I, Pittet D. Staffing level: a determinant of late-onset ventilator-associated pneumonia. Critical Care 2007; 11: R80.

11. Al-Rawajfah OM. Infection control practices among intensive care unit registered nurses: A Jordian National Study. Nurs Crit Care 2014;21(2):e20-e27 doi:10,1111/nicc.12078.

12. Yataklı sağlık tesislerinde yoğun bakım hizmetlerinin uygulama usul ve esaslari hakkinda tebliğ. Resmi Gazete tarih ve sayısı: 20/07/2011 tarih ve 28000 sayı Değişiklik Resmi Gazete tarih ve sayısı: 18/02/2012 tarih ve 28208 sayı Değişiklik Resmi Gazete tarih ve sayısı: 29/05/2013 tarih ve 28661 sayı

13. Stephan F, Ghiglione S, Decailliot F, Yakhou L, Duvaldestin $P$, Legrand P. Effect of excessive environmental heat on core temparature in critically ill patients. An observational study during the 2003 European heat wave. Br J Anaesth 2005; 94:39-45.

14. Schwab F, Gastmeier P, Meyer E.The Warmer the Weather, the More Gram-Negative Bacteria - Impact of Temperature on Clinical Isolates in Intensive Care Units Plos One 2014;9(3): e91105.

15. McDonald LC, Banerjee SN, Jarvis WR Seasonal variation of Acinetobacter infections: 1987-1996. Nosocomial Infections Surveillance System. Clin Infect Dis 1999; 29: 1133-1137.

16. Senbayrak Akcay, Inan A, Cevan S, Ozaydin AN, Cobanoglu N, Ozyurek SC, Aksaray S. Gram negativ bacilli causing infections in an intensive care unit of a tertiary care hospital in Istanbul, Turkey J Infect Dev Ctries 2014, 8(5):597-604.

17. Ramos GP, Rocha JL, Tuon FF. Seasonal humidity may influence Pseudomonas aeruginosa hospital acquired infection rates. Int J Infet Dis 2013; 17: e757-e761.

18. Fletcher $B A$, Lin $S$, Fitzgerald EF, Hwang $S$. Association of summer Temperatures with hospital admissions for renal diseases in New York State: a case crossover study. Am J Epidemiyol 2012; 175(9):907-16.

19. Falagas ME, Peppas G, Matthaiou DK, Karageorgopulous DE, Karalis $\mathrm{N}$, Theocharis $\mathrm{G}$. Effect of meteorological variables on the incidence of lower urinary tract infections. Eur J Clin Microbiol Infect Dis 2010; 28(6) :709-12.

20. Gaudart J, Cloutman-Green E, Guillas S, D'Archy N, Hartley Jc, Gant V, Klein N. Healthcare Environments and Spatial Variability of healthcare Associated Infection risk: CrossSectional Surveys 2013; 8(9:) e76249. 